\title{
Die sekerheid van die geloof by Calvyn en sommige van sy navolgers
}

\author{
AD Pont
}

\begin{abstract}
The thoughts of Calvin and some of his followers on the certainty of faith

In this paper Calvin's thoughts on the certainty of faith are traced as he expresses this in the Institutes. It is also shown that the Heidelberg Catechism faithfully follows Calvin's line of thought as the priority of faith over repentance and rebirth, which are seen as fruits of faith, is stressed. It is shown from the Institutes that for Calvin the certainty of faith lies in adhering in faith to the objectively given surety of the Word of God and His promises.

In the second part of the article it is shown how in Beza's work, in Calvinistic scholastic orthodoxy and in the Nadere Reformatie of the 17th and 18th century in the Netherlands there is a gradual shift of emphasis in this matter. The implications of this shift in accent is briefly discussed.
\end{abstract}

\section{VOORAF}

Dit is met' $n$ sekere mate van weemoed dat hierdie artikel opgedra word aan prof dr BJ Engelbrecht wat aan die einde van 1988 sy opdrag aan die Fakulteit Teologie neerlê. Hy het 'n lang en vrugbare verbintenis met ons fakulteit gehad, vrugbaar veral omdat hy, op sy manier, die teologie en denke wat prof dr HP Wolmarans hier tydens sy dienstyd van 1935 tot 1958 gevestig het, voortgesit het. Daarmee het prof Engelbrecht nie alleen die uitbou van die Bybels-reformatoriese teologie nie, maar ook die kerk gedien.

Toe ek aan die begin van 1957 op 'n betreklik jeugdige ouderdom by die fakulteit aangesluit het, het ek in prof Engelbrecht en, laat dit bygesê word, in prof ES Mulder, twee kollegas gevind wat alles in hulle vermoë gedoen het om my pad te effen. In meer gevalle as wat ek kan onthou, kon ek gebruik maak van prof Engelbrecht se merkwaardige geheue en kennis, asook sy skerp insig in teologiese vraagstukke en sy besadigde oordeel.

Daar was in ons fakulteit in die sestigerjare heelwat storms en 
tweespalt naas die veel langer periode van rus en gestadige vooruitgang. In al die jare het ek prof Engelbrecht leer ken as ' $n$ troue kerkman, 'n uitnemende wetenskaplike en 'n vriend.

Dit is seker nie vir my nodig om hiér 'n samevatting te gee van prof Engelbrecht se lys van prestasies nie. Tog wil ek graag, deur hierdie artikel aan hom op te dra, dit weer onderstreep dat soos ek dit beleef het al sy dienswerk, ook by die fakulteit, diensbaar was vir die kerk èn uitdrukking was van sy diensbaarheid aan die Heer van die kerk. Miskien is dit tog gepas om 'n Luther-woord ook van toepassing te maak op prof BJ Engelbrecht. Luther het gestel: 'So oft ein Theologe sein Amt versieht, bringt er Gott das angenehmste Opfer, wird in Wahrheit ein Priester der Allerhöchsten genannt und ist es auch.' Waar ons gemeenskaplike verbintenis aan die fakulteit nou ná 31 jaar saam in die tuig beëindig word deur sy aftrede, wil ek prof Engelbrecht dank, eer en alles van die beste toewens.

\section{INLEIDEND}

Die vraag na die sekerheid van die geloof is 'n saak wat telkens in die geskiedenis van die kerk opduik en dan van verskillende antwoorde voorsien word. Die feit dat Johannes Calvyn in sy Institutio ook daarop ingaan én dat die saak ook in die Heidelbergse Kategismus hanteer word, wil nog lank nie sê dat daarmee die saak in die Calvinistiese kerke afgehandel is nie. Telkens weer is hier sprake van 'n afwyking van Calvyn se Bybelse siening en omdat dit so 'n sentrale saak is, het dit telkens ook reperkussies in die kerk self gehad. Die belang van dié saak word verder onderstreep deur die feit dat Graafland in 1961 en Stadtland in 1972 uitvoerige studies aan dié saak gewy het. Die feit dat die Nadere Reformatie in Nederland van die 17de en 18de eeu 'n duidelike swaai weg van die opvattings van Calvyn verteenwoordig, bring mee dat die saak ook in ons kerk se geskiedenis deurgewerk het. Immers die oude schrijvers van die Nadere Reformasie waaronder veral W á Brakel, B Smijtegelt, C Mel en nog andere gereken moet word, het op ' $n$ bepaalde tyd 'n groot rol in die kerklik-godsdienstige opvattings van die republikeinse Afrikaner in die 19de eeu gespeel. Verder kan gestel word dat die opkoms van die samelewingsteologieë in die tweede helfte van ons eeu met hulle duidelike antroposentriese tendens, die saak van die sekerheid van die geloof by implikasie aan die orde stel. Daarom sal dit goed wees as kortliks en binne die bestek van 
'n artikel, 'n oomblik wéér na Calvyn se opmerkings in sy Institutio gekyk word. Daardie opvatting het die teologies-godsdienstige basis waarop ons as Calvinistiese kerk van die Hervorming wil staan, bepaal.

\section{SOLE FIDE}

As oor hierdie saak van die sekerheid van die geloof by Calvyn navraag gedoen word, dan kom vanself Boek IIl van die Institutio aan die orde. Dáár stel Calvyn dat die geloof 'n vaste vertroue op God is en met 'n beroep op 2 Tessalonisense 1: 11 en 1 Korintiërs 2: 4 benadruk hy dat die geloof nie uit die mens se eie beweging voortkom nie, maar ' $n$ werk van God in en aan ons is. Dán sê Calvyn (III.2.38):

Hieruit kan mens oordeel hoe verderflik die leer van die skolastici is dat ons, met betrekking tot die genade wat God aan ons gee, niks daaroor kan vasstel nie behalwe deur bespiegelinge oor die kwaliteit van ons dade. Indien uit ons werke vasgestel moet word hoe God ons gesind is, erken ek dat ons selfs deur die minste bespiegeling dit nie sal kan bepaal nie.

In hierdie één uitspraak is reeds die kern van Calvyn se standpunt weergegee. Calvyn stel met nadruk dat ons geen enkele sekerheid ten opsigte van God se gesindheid teenoor ons het nie as nét die sekerheid wat in die geloof sélf geleë is, 'n geloof wat dan vashou aan die evangelie, aan die beloftes van God. Daarom verwerp Calvyn elke poging om ' $n$ sekerheid te vind in byvoorbeeld die kentekens van die wedergeboorte, die bekering, die nuwe lewe van goeie werke of iets van daardie aard (Stadtland 1972: 161, 163).

Dit blyk verder dááruit dat Calvyn nadruklik stel dat die wedergeboorte ' $n$ vrug van die geloof is en dit verwerp dat die geloof ' $n$ vrug van die wedergeboorte sou wees. In die lyn van Calvyn stel die Heidelbergse Kategismus (S.25) as antwoord op die vraag:

... waar kom so 'n geloof vandaan? Van die Heilige Gees. Hy bring die geloof in ons harte tot stand deur die verkondiging van die heilige evangelie en versterk dit deur die gebruik van die sakramente.

As Calvyn sorgvuldig nagelees word, word dit duidelik dat poenitentia of bekering dieselfde as wedergeboorte beteken. Want, stel hy (III.3.5): 
'Dit ontgaan my sekerlik nie dat deur die woord poenitentia die hele bekering tot God verstaan moet word ...'

Daarom stel hy verder (III.3.9):

Altwee dinge (= die afsterwe van die ou mens en die lewendmaking) val ons te beurt deur ons deelgenootskap aan Christus. Want as ons werklik deel het aan sy dood, word ons ou mens deur sy krag gekruisig en sterf die liggaam van die sonde sodat die verdorwenheid van die eerste natuur nie meer krag sal hê nie. As ons aan sy opstanding deel kry, word ons daardeur tot 'n nuwe lewe opgewek wat beantwoord aan die geregtigheid van God. Met een woord gesê: Ek verstaan onder poenitentia die wedergeboorte wat nie ' $n$ ander doel het nie as om die beeld van God wat deur Adam se oortreding besoedel en byna uitgewis was, weer in ons te herstel.

Met klem stel Calvyn dat die poenitentia, bekering, wedergeboorte nie 'n voorbereiding nie, maar 'n vrug van die geloof is (III.3.1). So stel hy (III.3.2):

Maar wanneer ons sê dat die oorsprong van die poenitentia in die geloof lê, droom ons nie van 'n tydruimte waarin die geloof besig is om dit voort te bring nie, maar wil ons slegs stel dat ' $n$ mens hom nie met erns op die poenitentia kan toelê nie tensy hy wéét dat hy aan God behoort.

En niemand is werklik oortuig dat hy aan God behoort as slegs hy wat in die eerste plek God se genade aangegryp het.

Dit is nogal opvallend hoe duidelik die Nederlandse Geloofsbelydenis (NGB), Art 24 hierdie opvatting van Calvyn weergee èn onderstreep:

Ons glo dat hierdie ware geloof in die mens voortgebring word deur die werking van die Heilige Gees; dat dié geloof hom weergebore laát word en tot 'n nuwe mens maak, hom 'n nuwe lewe laat lei en hom bevry van die slawerny van die sonde.

Daarom is dit ook belangrik om te let op die volgorde wat Calvyn in Boek III handhaaf in dié sin dat hy na 'n uiteensetting oor die geloof éérs handel oor die bekering en die nuwe lewe van die gelowige, (III.3-10) voordat hy oor die regverdiging (III.11-18/19) en die uitver- 
kiesing (III.21 vg) 'n uiteensetting gee (vgl Stadtland 1972: 109-114).Dit is opvallend dat Calvyn hierin die sola fide van die Hervorming en die rol van die regte verkondiging en hoor van die Woord van God deur die werking van die Heilige Gees, 'n duidelike primaat toeken. Die geloof as genadegawe van God aan die mens gaan vooraf, die genade is méér as die mens (vgl onder andere Graafland 1961: 37-40).

\subsection{Die sekerheid}

As daar nou gevra word na die sekerheid van die geloof, die sekerheid wat die gelowige soek om so te weet dat hy inderdaad ' $n$ kind van God is, is dit interessant om vas te stel dat Calvyn géén subjektiewe grond vir die sekerheid wil aanvaar nie. As die Institutio III.11-20 nagelees word, word dit duidelik dat Calvyn oordeel dat die nuwe lewe van die wedergebore gelowige nie as 'n bewys kan dien dat die mens inderdaad ' $n$ kind van God is nie. Dit kan gestel word dat die Heidelbergse Kategismus S.23-24 en ook 44 eintlik 'n opsomming is van Calvyn se standpunt hoewel die Kategismus die regverdiging as eerste vrug van die geloof beklemtoon (S.23). Eers in S.24 en dan in S.33 en 34 word die dankbaarheid, die goeie werke èn die bekering as vrugte van die geloof na vore gebring. As die Institutio III.11.1 oor die regverdiging nagelees word, blyk dit dat, ondanks die orde waarin Calvyn die sake behandel, daar géén inhoudelike verskil tussen die Institutio en die Kategismus is nie. Dit is opvallend hoe Calvyn Luther se sola fide by die regverdiging net so oorneem (III.11.19.20) en dat die Kategismus S.23 dit óók onderstreep.

Daarom stel Calvyn (III.14) ook met soveel klem dat die geloof 'n genadegawe van God is wat ons as mens nié kan verdien nie en waarvoor ons onsself ook nie bekwaam kan maak nie (III.14.11-13). Daarom wys Calvyn dit ten ene male af dat die goeie werke van die gelowige of die nuwe lewe wat 'n vrug van die geloof is, ons enige geregtigheid toebring (vgl ook Kategismus. S.24) en daarom sê hy nadruklik dat ons regverdigheid alleen rus op die barmhartigheid van God, alleen in ons deelgenootskap aan Christus en daarom alleen in die geloof wat nié op goeie werk kan steun nie (III.15.1). Elke gedagte aan verdienste in die nuwe lewe van die gelowige sien Calvyn as ' $n$ poging om die eer van God aan te rand. Hier beroep Calvyn hom op Romeine 6: 23 (III:14.21). Daarom kan die sekerheid van die geloof nooit gevind word in die wedergeboorte of die nuwe lewe nie.

Daarby stel Calvyn net so nadruklik dat die sekerheid van die geloof 
en dus die verkiesing nêrens anders gevind kan word as om te glo in God se beloftes in sy evangelie waar die goeie boodskap gehoor word dat ons uit genade, om Christus wil, regverdig verklaar word. Vir Calvyn is die geloofsekerheid objektief veranker.

Maar dan laat Calvyn tog 'n klein uitsondering toe (III.14.18) wanneer hy sê:

Wanneer ons die vertroue op die werke uitsluit, wil ons slegs dit sê dat 'n Christen hom nie moet wend tot die verdienste van sy werke as 'n soort hulp vir die saligheid nie, maar dat hy hom geheel en al verlaat op die belofte van die onverdiende regverdigheid.

Maar ons verbied dit nié dat hy sy geloof sal stut en versterk met die tekens van God se goedheid teenoor hom nie... Wanneer die heiliges hulle geloof versterk deur die onskuld van hulle gewetes en daaroor bly is, doen hulle niks anders nie, as om uit die vrugte van hulle roeping te besluit dat hulle deur die Here tot sy kinders aangeneem is.

Dieselfde argument vind ons terug in die Kategismus S.32 waar gestel word:

Nadat Christus ons met sy bloed gekoop en vrygemaak het, vernuwe Hy ons ook deur sy Heilige Gees tot sy ewebeeld, sodat ons met ons hele lewe kan bewys dat ons God dankbaar is vir sy weldade en Hy deur ons geëer kan word. Vrede, sodat ons vir onsself uit die vrugte van die geloof sekerheid kan kry, en ons deur ons godvresende lewe ons naaste ook vir Christus kan wen.

Dit is dus wèl duidelik dat die mens geen genade kan verdien nie. Maar hy kàn wel goeie werke doen omdat Christus hom vernuwe of weergebore láat word sodat die gelowige God kan vereer, sodat hy sy naaste tot heil sal wees én sodat hy '. . . uit die vrugte van die geloof sekerheid kan kry.' Calvyn self stel die saak baie versigtig en is van mening dat die geloofsekerheid alleen moontlik is wanneer die geloof reeds op die vaste fondament van God se beloftes in Christus gegrond is. Opvallend is dit dat Calvyn nié die goeie werke noem as 'n moontlike teken of bewys van die uitverkiesing nie. Dit is dus duidelik dat Calvyn self hier met groot versigtigheid diě saak stel (vgl onder andere Stadtland 1972: 173).

Dit is dus duidelik dat die sekerheid van die geloof, die sekerheid 
van die heil, nie in die mens self gesoek moet word nie. Alhoewel die objek van die geloof nie sigbaar is of bewys kan word nie, kan die gelowige seker wees van die heil. Sekerheid beteken immers vir Calvyn die sekerheid van die persoonlike deelgenootskap aan die genadewerk van God in Jesus Christus en dit is duidelik dat sonder sekerheid die mens nie 'n gelowige kán wees nie (vgl Komm I Joh 5: 19). Daarmee stel Calvyn egter nie dat álle twyfel uitgeskakel word nie, want die geloof word nog steeds weerspreek omdat die mens deur die geloof in Christus nie 'n sondelose word nie. Maar die gelowige kan nie meer uit die hand van God val nie (III.2.17). Tog kan die geloof alle twyfel oorwin omdat dit voortdurend deur die Woord van God opgebou èn versterk word (III.2.21). Daarom knoop Calvyn die geloofsekerheid ook vas aan die vertroue op die vergewing van die sonde om Jesus Christus ontwil (vgl Komm Rom 4: 6). Die sekerheid van die heil hang vir Calvyn saam met die feit dat die Heilige Gees die gelowige leer dat God hom goedgesind is hoewel hy duidelk stel dat die gelowiges nie 'n ekstra openbaring nodig het om aan hulle te sê dat hulle uitverkore is nie. Hoewel die gelowige in hierdie lewe vanweë sy sonde tog nog stryd moet voer teen die twyfel, is daar tóg vir die gelowige bewyse van sy onverbreekbare verbintenis met God, onder andere in die vasstaande belofte van die onverdiende regverdiging (III.14.18). Sekerheid van die geloof, sekerheid van die heil en sekerheid van die uitverkiesing lê vir Calvyn op één lyn en is onverbreekbaar verbind met die genadegawe van die geloof. Daarom sê Graafland (1961: 69) tereg dat by Calvyn die geloof sekerheid is. Dié sekerheid is gebou op die beloftes, die Woord van God en in die grond van die saak op God sélf.

\subsection{Die vervolg}

Die saak van die geloofsekerheid het na Calvyn 'n moeilike pad gegaan, soos Graafland aantoon. Die interessante is dat hierdie ontwikkeling ook 'n wysiging in die kerkbegrip meebring. Dit spreek vanself want die vraag na die geloofsekerheid is die vraag na die sekerheid oor die verbondenheid met God deur Jesus Christus en dus ook die vraag na die gemeenskap van die heiliges, die kerk (NGB 27).

Die merkwaardige is dat die eerste afwyking van hierdie opvattings al by Theodorus Beza, 1519-1605, leerling en opvolger van Calvyn en invloedrykste vormgewer van die Calvinistiese ortodoksie vir byna veertig jaar (Bray 1975: 138), vasgestel kan word. Waarskynlik hang dit daarmee saam dat die leer van die uitverkiesing, wat by Calvyn in 
sekere sin die afsluiting vorm van sy Skriftuurlik bepaalde opvattings oor die verhouding tussen God en mens (Bray 1975: 138), nou tot die uitgangspunt van die teologiese denke en 'n soort simbool van regsinnigheid word (Graafland 1961: 67). Daarmee gebeur die merkwaardige wat Graafland (1961: 68) as volg omskrywe:

Want wanneer, zoals Beza doet, het geloof en het ongeloof geheel afhankelijk worden gemaakt van het eeuwig besluit der verkiezing en der verwerping, ook in zijn nadere uitwerking, kan de belofte aan de verworpenen niet meer worden aangeboden. Het eeuwig besluit overheerst de verkondiging.

Hoewel Beza met dié opvatting nie altyd konsekwent is nie, is dit tog so dat vir Beza die sekerheid van die uitverkiesing 'n groter vraag is as dié na die sekerheid van die geloof (Bray 1975: 140). Die vraag na die heilsekerheid word deur Beza dan beantwoord deur te wys, enersyds op die uitwendige getuienis van die goeie werke wat die gelowige doen en andersyds op die inwendige getuienis van die Heilige Gees in die gewete. Weliswaar stel hy dat hierdie dubbele getuienis van die werke en die gewete voortkom uit die geloof in Christus, maar dit is tog baie anders as Calvyn wat leer dat die geloof die sekerheid is (Graafland 1961: 69).

Hier lê dan die oorsprong vir die belangstelling vir die vrome, wedergebore subjek wat in die Nadere Reformasie nog verder deurgevoer word. Dit dan ook vanweë die feit dat die Sinode van Dordrecht 1618-19 so 'n duidelike aksent op die uitverkorenheid van mense gelê het. Hoewel die canones dit benadruk dat die mens géén bydrae lewer tot sy heil nie, is dit opvallend dat die heilsorde van die canones van dié van Calvyn verskil en dat nie met die geloof begin word nie (Krüger 1974: 164). Daar is ook in die canones 'n belangrike aksent op die merktekens van bekering, wedergeboorte en uitverkiesing (1: 12) wat daartoe meegewerk het dat ná Dordt dit gebruiklik word om na die kenmerke van die wedergeboorte in die lewe van die gelowige te soek (De Vrijer sa: 10-12). Die canones, hoewel nog volkome in lyn met die inhoud van die Calvinistiese reformasie, staan op die grens van die waterskeiding en lê hiér en daar aksente wat algaande in die Nadere Reformasie oorbeklemtoon word, teen die bedoeling van die canones in. Hoewel dit waar is dat die canones al tekens toon van die indringing van die skolastieke metode in die teologie, staan die canones in sy essensie as 'n baken van die Reformatoriese grondstelling dat die geloof eksklusief ' $n$ genadegawe van God is wat aan die mens gegee word 
deur die verkondigde woord, die viva vox evangelii. Dit bly waar: Dit is genade om genade te ontvang.

Met hierdie beweging èn met die benadrukking van die uitverkiesing as uitgangspunt en sentrale leerstuk van die kerk word die genadeverbond as die reële, empiriese grondslag van die kerk geleidelik opsy geskuiwe. Hoewel dit waar is dat die Nadere Reformasie bedoel het om slegs die lewe te hervorm as 'n theologia practica, bring die vraag na die sekerheid van die uitverkiesing tog 'n aksentverskuiwing mee, want die aandag word nou al meer gevestig op die mens, die kwaliteit van sy geloof en lewe. Diě aksentverskuiwing bring aanvanklik nie ' $n$ verskuiwing in die teologie na vore nie, maar mettergaan wél. Dán word die sigbare merktekens van die uitverkorenheid van die mens 'n saak van gewig en gaan dit nié meer, in die eerste plek om God en sy groot dade nie, maar om die méns en sy reaksie, ervaring en belewing van die heil en word die kwaliteit van die mens se reaksie die maatstaf waarmee die egtheid van God se genade gemeet word. Net dáár en presies so word die sola fide van die Reformasie verloën en word die evangelie gedepresieer. Met ' $n$ reusesprong in die geskiedenis kan terloops gesê word dat dit eers Kohlbrügge in 1833 met sy beroemde preek oor Romeine 7: 14 was wat hierdie ontwikkeling aan die kaak gestel het.

Om verder te gaan, juis vanweë hierdie uitgangspunt en met so 'n beklemtoning van die uitverkiesing, die wedergeboorte en die bekering, word sowel die geloof as unieke genadegawe van God, waaruit álles verder vir die mens voortvloei (HK, S. 23) as die genadeverbond misken en word die verborge wil van God ten koste van die geopenbaarde wil van God beklemtoon.

Dié hele gedagtewêreld word dan verder oorgedra, byvoorbeeld na die kerkbegrip en dan word gestel dat die lede van die kerk nie die gedoopte gelowiges is nie, maar alleen dié lede van die kerk wat ook die kentekens van die wedergeboorte besit. Sodra dít gebeur, ontstaan daar 'n kerkie binne in die kerk, daar ontstaan besware teen die doopformulier, 'n wettiese vermyding van 'die wêreld' en 'n opbloei van die konventikelwese. Dit is in die Nadere Reformasie byna vanselfsprekend dat die ernstige gelowiges, soos hulle hulleself genoem het, hulle as 'ware kerk' afsonder van die res van die gemeente wat dan as 'wêrelds' aangedui word. Dit hang juis saam met die omkeer van die belangstelling van die objektiewe na die subjektiewe. Die ware gelowiges is so besig om te konsentreer op hulle innerlike toestand en belewing van die wedergeboorte (vg DL III en IV, 11-12) dat hulle nie 
meer kans sien om hulle nog verder met die res van die kerk of die goddelose wêreld te bemoei nie. So word die genadeverbond versmal en gebeur dit, soos by De Labadie, dat ook die tekens van die verbond, naamlik doop en nagmaal, vermy word. Juis hierdie kenmerke van die Nadere Reformasie dui daarop dat hierdie beweging nie 'n ontwikkeling of ' $n$ nadere toepassing van die eerste reformasie was nie, maar veel eerder 'n verwording, ' $n$ terugval op dié denkbeelde wat die 16de eeuse Reformasie afgewys het.

So gebeur dit dat in die geloofslewe van die Nadere Reformasie die sola fide van Luther en Calvyn sy sentrale plek verloor en dat dit deur die leer van die wedergeboorte vervang word. Dan word die vraag na die vrugte van die wedergeboorte as soveel kenmerke van die uitverkiesing sentraal gestel. So gebeur dit dat die leer van die uitverkiesing en die besondere genade die basis word van separatisme, want met so ' $n$ indiwidualistiese verkiesingsleer is daar nie meer plek vir die verbond nie en ook nie vir 'n kerk nie.

\subsection{W á Brakel}

Indien hierdie ietwat skerp afwysing van die Nadere Reformasie as verwording gestel word, is dit miskien tog interessant om 'n oomblik te let op die gedagtes van $\mathrm{W}$ á Brakel, 'n figuur wat ook in die dampkring van die Nadere Reformasie gestaan het. Dit is in ons kerklike leefwêreld belangrik, want á Brakel se min of meer populêre dogmatiek, Redelyke Godtsdienst, het 'n groot invloed gehad op die denke van die vroeë republikeinse Afrikaner (vg onder andere GBA Gerdener 1930: 222 e a).

In á Brakel se omvattende werk, wat die eerste maal in 1700 verskyn het en daarna dikwels herdruk is, kan ook 'n voorbeeld gesien word van die 17 de en 18de eeuse Calvinistiese skolastieke ortodoksie soos dit in die Nadere Reformasie verwerk is. Met sy geesgenoot, Jac Koelman, is á Brakel ook 'n navolger van William Ames, teologiese hoogleraar te Franeker, en vertoon hy' $n$ besondere belangstelling vir die merktekens wat die ware gelowige of uitverkorene moet (kan) vertoon van sy roeping, bekering, wedergeboorte, geloof, regverdiging en heiligmaking. Dit sou seker te ver voer om hier in te gaan op die kwaliteit van die Calvinistiese skolastiek. As Armstrong (1969: 32 vv) nagegaan word, is dit duidelik dat á Brakel, hoewel hy vierkantig binne die Nadere Reformasie staan, in die vormgewing van sy opvattings deur dié skolastiek beïnvloed is. Hoewel á Brakel nog steeds met sy opvattings binne die raamwerk van die 17 de en 18 de eeuse Calvinistiese ortodok- 
sie bly, is daar tog 'n duidelike verskil tussen sy gesistematiseerde, skolasties-bepaalde teologie en die Institutio van Calvyn. Die verskil tussen Calvyn en sy skolastieke navolgers kan, vir 'n oomblik, nader belig word deur te let op 'n omskrywing van Armstrong (1969: 34-35) in dié verband:

Indeed, if there is a persistent theme in Calvin it is that God's ways and thoughts are incomprehensible to man without special revelation. His theology then is an expression of faith and complete trust in God, written by a man of faith to encourage and aid the faithful of God. As such the rational dimension is clearly subordinated to the religious. In this program theology is designed not to meet the demands of a rationally acceptable and defensible system but to assist the faithful in understanding God's revelation.

By á Brakel is dit gesistematiseerde teologie met 'n sterk opbouende inslag, wat antwoorde wil verskaf op elke moontlike vraag wat gestel kan word. Trou aan die Calvinistiese ortodoksie is die uitgangspunt en voortdurende verwysingspunt van sy sisteem die leer van die uitverkiesing wat breed in die sesde hoofstuk uitgemeet word en logies ingepas word tussen die hoofstukke wat handel oor God en die Drie-eenheid en die skepping. Hier word dit terloops duidelik dat die uitverkiesing en die verbond van die genade in 'n sekere spanning gestel word en dat á Brakel die verbond nie meer sien as die voorwerp van die uitverkiesing nie. Dit is egter duidelik dat á Brakel met sowel die uitverkiesing as die verbond wil beklemtoon dat in die verhouding van God en mens, God die handelende is en dat $\mathrm{Hy}$ vir die mens die heil tot stand bring en in sy genade gee.

Nou is die interessante dat á Brakel, ondanks die feit dat hy nie moeg word om die Remonstantse opvatting te veroordeel nie, 'n besondere belangstelling bly vertoon in die reaksies van die mens op die genade wat God aan sy uitverkorenes gee.

In sy uitvoerige bespreking, en niks word deur á Brakel vinnig of oppervlakkig afgehandel nie, behandel á Brakel die volgende stadia: die roeping, die wedergeboorte, die geloof, die kentekens van die geloof, die regverdigmaking, die kindskap en dan die vrede met God. Tog beklemtoon á Brakel (1736: I, 762):

't Geloove gaet voor de Wedergeboorte wel niet in tydt maer in ordere der nature; want het woordt is het zaet der Wedergeboorte ... en het woordt kan geen nut doen dan door het Geloove. 
Daarby stel hy dat die geloof genade is, maar stel nêrens dat die geloof 'n genadegawe van God is nie. Dit is opvallend dat die vraag wáár die geloof vandaan kom, deur á Brakel nie werklik behandel word nie. Dit hang waarskynlik saam met á Brakel se voorliefde om oor die mens en sy ervarings te praat in plaas van God en sy groot ontferming. Die geloof wat bestaan uit ' $n$ vertroue op God deur Jesus Christus is by á Brakel die beginpunt van alle geestelike lewe en beteken dat die mens hom in vertroue oorgee aan Christus, Hom aanneem sodat $\mathrm{Hy}$ die gelowige regverdig maak.

Maar dan verskuif sy aandag heeltemal na die mens en wy hy uitvoerige besprekings aan die vrugte van die geloof, waar hy wel die regverdigmaking noem, maar nie die bekering en die wedergeboorte, soos Calvyn nie. Verder het hy ook belangstelling vir die kentekens van die ware geloof en telkens word dit beklemtoon dat alléén die uitverkorenes die geloof en wat daarmee saamgaan, ontvang. Daarom is dit van wesenlike belang om te kan vasstel wie die uitverkorenes is en vandaar word die uitvoerige, byna resepmatige aanduidings gegee hoe die gelowige mens hom nie net in die geloof kan oefen nie, maar ook kan vasstel, skynbaar bo alle redelike twyfel, of hy 'n gelowige is of nie. Hier is die sekerheid van die geloof nie meer, soos by Calvyn, die sekerheid en vaste vertroue op die beloftes van Godin sy evangelie nie, maar' $n$ sekerheid wat opgebou word uit die ervaring van die mens van die genade, die wedergeboorte, die bekering èn die ontvang van die geloof wat lei tot die regverdigmaking. Daarby word voortdurend beklemtoon dat dit alles nét die uitverkorenes geld en word gestel dat nie almal wat die evangelie hoor, of wat gedoop is of kerk toe gaan of die Nagmaal gebruik, ware gelowiges, uitverkorenes kán wees nie. Alles draai dus nie meer primêr om God en sy groot dade nie, maar, so wil dit voorkom, om die vraag of die gelowige voldoen aan al die ingewikkelde en uitvoerige voorwaardes wat gestel word as die maatstaf om te bepaal of hy uitverkies is. Daarom sê á Brakel (1736: I, 748):

'. . . ' $t$ is noodigh, als men op goede gronden uyt het Woordt Godts en uyt goede kennisse van zijn herte en de daden besluyten kan dat men gelooft ende wedergeboren is, ...'

Die geloofsekerheid wat in 'n meerdere èn mindere mate ervaar word, kan in drie stadia of selfs trappe ervaar word. Die eerste is die oefening van die geloof waardeur die gelowige homself met die Woord van God vergelyk. So kan hy vasstel of hy wedergebore is en uit die Gees van Christus leef. So kan die gelowige op grond van die Woord en deur die 
werking van die Heilige Gees tot sekerheid kom (á Brakel 1736: I, 771 $\mathrm{vg}$ ). Die tweede moontlikheid is dat die Heilige Gees aan die gelowige openbaar dat God in Christus Jesus hom liefhet. So kan die mens, in groot blydskap, seker wees dat hy aan God behoort. (á Brakel 1736: I, 180). Die derde is die oefeninge in die geloof wat op 'n selfbeproewing uitloop (á Brakel 1736: I, 801) en waaroor hy 'n hele hoofstuk skrywe onder die opskrif 'Kenteekenen van het saligmakende geloove'.

á Brakel stel dit uiteindelik dat geloof deur die Woord die verbondenheid met Christus skep, sodat die gelowige met Christus as middelaar by God self kan uitkom. So is die geloof die middel wat die verband tussen God en mens lê. Tog is dit wel van belang dat á Brakel, wanneer hy handel oor die maniere of moontlikhede waarop die gelowige tot sekerheid kan kom, as 'n tweede moontlikheid noem dat die Heilige Gees aan die gelowiges die sekerheid gee en dan, teen die Calvinistiese leer in, Gees en Woord van mekaar losmaak. Hier lê 'n yslike slaggat verskuil in sy betoog en dit waarskynlik omdat á Brakel onder Woord nie altyd Jesus Christus verstaan nie. Immers as die verkondigde Woord nie verkondiging van Jesus Christus is nie, as die prediking vervlak tot allerlei mens-gesentreerde toesprakies, dan is dit nie meer regte prediking nie. As die verkondigde Woord die middel is wat die Heilige Gees gebruik om die geloof aan die mens te gee, en as geloof niks anders kan wees nie as die definisie soos gegee in die Nederlandse Geloofsbelydenis 22, dan kan die regte prediking nooit iets ánders wees as Christusverkondiging nie.

Wat by á Brakel opvallend is en gesien die situasie waarin hy staan, ook vanselfsprekend vanweë die struktuur van sy teologiese sisteem, is dat hy voortdurend beklemtoon dat die geloof en die geloofsekerheid nét vir die uitverkorenes bedoel is. Hoewel hy dié saak nie op die spits dryf, soos byvoorbeeld die Labadiste nie, is dit tog duidelik dat hierdeur duidelik in die gemeente èn in die kerk 'n verdelingslyn getrek word tussen die uitverkorenes wat kan vasstel dat hulle uitverkies is en die ander lidmate van die kerk. á Brakel is baie stellig dat die verkondigde Woord nét vir die uitverkorenes bedoel is (á Brakel 1736: I, 715).

'n Interessantheid wat daaruit voortvloei is dat á Brakel, wanneer hy oor die roeping tot die geloof handel, dit duidelik stel dat die Woord van God vryelik verkondig moet word maar tog ook weer nie aan alle mense nie. Soos hy dit stel (1736: I, 704). 
Wy seggen niet alle menschen maer wel geheele Landtschappen, Natien, Volkeren ende Talen, doch niet alle; want de geheele Schrift ende de ervaerentheyt van alle tyden is daer tegen.

Dit sal tog van belang wees, gesien die besondere waardering wat á Brakel geniet het onder die republikeinse Afrikaner en sy kerk, om te probeer vasstel of dié opvatting nie nog verder deurgewerk het nie. As in ag geneem word dat die opvattings van Aegidius Francken in hierdie verband ' $n$ kerklike skeuring veroorsaak het (Pont [1960-1961]: $89 \mathrm{vv}$ ), ontstaan die vraag of die verstaan van á Brakel nie in 1910 die agtergrond was van die kerklike skeuring in Humpata nie. Maar daaraan kan daar nie nou aandag gegee word nie.

Dit toon wéér dat daar ' $n$ fout is in die struktuur van á Brakel se teologie en dié strukturele fout lê daarin dat, anders as by Calvyn self, die leer van die uitverkiesing die uitgangspunt van sy teologiese denke is en nie die slothoofstuk nie. Dit kom weer daarby dat nie God Drie-enig in die sentrum van dié teologie staan nie, maar die mens. Dat daardie opvatting in die kerk en in die godsdienstige lewe van die mense van die kerk allerlei misverstande en nood veeroorsaak het, blyk nie net uit die geskiedenis van die kerk nie, maar word ook duidelik as die vroomheidstipe wat deur á Brakel se opvattings gekweek is, ontmoet word.

\subsection{Slotopmerkings}

As hierdie gegewens oor die sekerheid van die geloof so nagegaan word, is dit tog opvallend hoe die aksent verskuif het. Dit is veral belangrik om daarop te let omdat in ons kerklike verlede die kennis van Calvyn en sy werk grotendeels deur middel van die Nadere Reformasie plaasgevind het. In 'n sekere sin het ons vadere die Calvinisme beter geken as die werk van Calvyn. Dit bring mee dat, waar Calvyn die geloofsekerheid objektief veranker het en dit so doen tot troos en bemoediging van die gelowiges wat in die 16de eeu onder allerlei vorms van druk gestaan het, word die saak van die geloofsekerheid algaande omvorm tot 'n kenmerk van die ware gelowige en word so die aandag afgetrek van God en gerig op die mens wat die kenmerke en bevindings van die egte geloof moet kan vertoon.

By Calvyn is dit duidelik dat die Woord van God die spieël is waarin God Hom aan die mens openbaar en deur die Woord skep God self 'n verbintenis met die mens. Deur die werking van die Heilige Gees open 
God die hart en gemoed van die mens vir die Woord en omvorm $\mathrm{Hy}$ die mens sodat hy die Woord glo en aanvaar. Vir Calvyn is die sekerheid van die begin af ' $n$ eienskap, deel van die geloof en die betroubaarheid van die beloftes van God is die vaste steunpunt vir die geloof. Hoewel Calvyn die geloof sien as 'n resultaat van die uitverkiesing, stel hy tog dat daar nie na die uitverkorenheid buite die geloof in Christus om, gevra moet word nie.

Hoewel die canones van Dordrecht tereg ' $n$ algemene verlossing afwys en beklemtoon dat die heil in Christus alleen aan die ware gelowiges, die uitverkorenes gegee word, het die skolastieke ortodoksie en die Nadere Reformasie, met sy beklemtoning van die praxis pietatis, tog weer die mens na vore gebring. Daarmee is, miskien onbedoeld, juis wéér in die kettery van Arminius en die Remonstrante nuwe lewe geblaas, as die konsekwensies van die Nadere Reformasie getrek word deur die piëtisme, die metodisme en die moderne samelewingsteologieë wat op die wortel van die metodisme stoel. De Vrijer (sa: 286) het van Schortinghuis en sy navolgers gestel:

Hy wil, als alle piëtisten, dat de aanhangers van het dogma der Kerk dit dogma doorleven. Het weten van de waarheid is hun niet genoeg. Vandaar de nadruk op wedergeboorte, bekering; op maatschappelijke doorvoeren van de eischen van het Evangelie; op 'precisiteit'; de verwerping van adiaphora - met het gevaar het Verbond van God met Zijn Kerk op de tweede plaats te stellen, het Sacrament uit zijn centrale plaats te dringen; het gevaar van cultuur-loosheid en eenvormigheid; van scrupulose en geestelijke hoogmoed, van individualisme en verheffing van eigen godsdienstige gevoelens boven de vastheid van de door God geschonken rechtvaardiging door het geloof alleen.

As die negatiewe van hierdie ontwikkeling binne die Calvinistiese ortodoksie so beklemtoon word, is dit ook om te benadruk dat die Calvinisme as sodanig nie altyd die basies grondgedagtes van Calvyn self uitdra nie. Die Nadere Reformasie het een kardinale stelling van Calvyn (Simpson 1984: 114) nooit werklik volledig deurdink nie, naamlik:

Verder staan dit vas dat die mens nooit tot suiwer kennis van homself kom nie, tensy hy eers die aangesig van God aanskou het en uit die aanskoue van God tot ' $n$ ondersoek van homself neerdaal. Want - en dit is die hoogmoed wat in ons almal 
aangebore is - vir onsself lyk ons altyd regverdig, onberispelik, wys en heilig, behalwe as ons deur duidelike bewyse van ons onregverdigheid, ons afstootlikheid, ons dwaasheid en onreinheid oortuig word. Maar ons word nie hiervan oortuig solank ons ons oë net op onsself en nie ook op die Here rig nie. Hy is die enigste maatstaf na aanleiding waarvan ons hierdie oordeel moet meet.

Daarom sal, ook in ons dae, dit belangrik wees om méér te let op die geskrifte van Calvyn self, as op dié wat voortgekom het uit die Calvinisme, as ons vas wil staan op die basis van die Bybels-reformatoriese Teologie.

\section{Literatuurverwysings}

ARMSTRONG, BG 1969. Calvinism and the Amyraut heresy: Protestant Scholasticism and Humanism in the seventeenth century. France. Madison.

á BRAKEL, W 1736. Redelyke godtsdienst. Rotterdam: Van den Aak.

BRAY, JS 1975. Theodore Beza's doctrine of predestination. Nieuwkoop: De Graaff.

CALVINUS, J 1559. Institutio christianae religionis.

DE VRIJER, MJA sa. Schortinghuis en het innige Christendom. Heiden-Harderwijk: Reijnders.

GRAAFLAND, C 1961. De zekerheid van het geloof. Wageningen: Veenmann en Zonen.

GERDENER, GBA 1930. Boustowwe vir die geskiedenis van die Nederduits Gereformeerde Kerk in die Transgariep. Kaapstad: Nasionale Pers.

KRÜGER, JC 1974. Die verhouding van uitverkiesing tot bekering met spesiale verwysing na die Dordtse Leerreëls. Pretoria: NG Kerkboekhandel.

PONT, AD [1960-1961]. 'n Ontleding van die teologies-dogmatiese agtergrond van ds SD Venter se afskeiding van die Gereformeerde Kerk in die OVS. HTS 16.

SIMPSON, HW (vert) 1984. Institusie van die christelike godsdiens deur Johannes Calvyn. Potchefstroom: Calvyn Jubileum Boekefonds.

STADTLAND, T 1972. Rechtfertigung und Heiligung bei Calvin. Neukirchen KreisMoers: Buchhandlung der Erziehungsuereius. 